\title{
Identifying Tourism Products in Kampung Bukit Laka in the Jempol District of Negeri Sembilan, Malaysia
}

\author{
Syed Munir Barakbah Syed Faozi Barakbah
}

Faculty of Business and Technology, UNITAR International University, Malaysia.

\author{
Amri Ahmad \\ Faculty of Business and Technology, UNITAR International University, Malaysia. \\ Mohammad Nursyafiq Hamdan \\ Faculty of Business and Technology, UNITAR International University, Malaysia. \\ Received May 02, 2021; Accepted August 05, 2021 \\ ISSN: $1735-188 X$ \\ DOI: 10.14704/WEB/V18SI05/WEB18209
}

\begin{abstract}
This paper is an exploratory study on ecotourism and nature tourism products in Kampung Bukit Laka and its surrounding area, in the district of Jempol, Negeri Sembilan. The village of Kampung Bukit Laka is situated in Batu Kikir and is the main focus area of study. The study investigated on the availability of resources in those areas and identifying them as potential tourism products, and also the potential issues and challenges. A qualitative research design was appropriate since the data and information were collected via observations by a team of 4 research assistants which were guided by the resource instruments checklist that comprised of site, community, cultural, and natural resources. Another primary data collection method was the use of interviews with open-ended questions structure. The interviews were conducted with the community leaders and community members to ensure the validity of the findings from the observation's sessions. The findings indicated that there were limited types of resources that would be attractive to tourists, but there were some natural resources that had the potentials to be developed as ecotourism sites.
\end{abstract}

\section{Keywords}

Ecotourism Products, Natural Resources, Community Analysis, Tourists Attractions.

\section{Introduction}

The Kampung Bukit Laka is located in the area of Batu Kikir, which is a small town in the Jempol region in the eastern part of the state of Negeri Sembilan, Malaysia. It lies in the proximity of the town of Bahau, Serting, Juasseh and Kuala Pilah. Kampung Bukit Laka had not been known as a tourist destination although there were many natural 
elements that could be developed as tourism sites, especially ecotourism and nature tourism sites (Bernama, 2017). The area had been relatively unexplored yet. The Negeri Sembilan state tourism office had been recognised in the country as one of the most proactive in identifying new tourism products, but it would be the decisions of the community members and leaders as to whether they would want to be designated as tourist destination sites. The focus of tourism products in the Kampung Bukit Laka area would be for the development of ecotourism products due in part to the hilly and thick forest areas surrounding the area. The community involvement in tourism development would have to consider firstly, the readiness and willingness of the community to accept tourism as the means to improve their livelihood, and secondly, to determine the extent of the involvement of the community in the planning, developing, and maintenance of the tourism sites (Reed, 1997). The next issue would be to ensure that the community members would monetarily gained from those projects, and that the benefits would be fairly distributed.

The research objectives would be to determine the drawing factors through the assessment of the site, the community, the cultural, and the natural resources. It would then determine whether there would be sufficient tourism packages that could be developed. Upon that, the possible tourist segments would be identified. There would also be the need at the early planning phase, to ensure that the resources would not be depleted and that they would be properly conserved as any touristic activities especially ecotourism activities would bound to impact on the preservation of the natural environment.

The research process was divided into three phases:

Phase 1: Situation Analysis which encompassed the analysis of the site, community analysis, nature and cultural resources. Detailed the summary of the findings.

Phase 2: Identification of potential and viability of the natural attractions and ecotourism products. Suggest the development of tourism package (if any).

Phase 3: Identification of target market segments (if necessary).

\section{Literature Overview}

Hofstede (1991) and Trompenaars (1993) defined culture which included the people values expressed through their languages, economy, religion, policies, social institutions, class, values, status, attitudes, manners, customs, material items, and education. According to Fallahi (2008) cultural heritage is very important in fostering the quality of life with values and pride in all civilizations. It comes together with an historic message 
and information that the cultural materials transmit from the past to the present and the future.

Nature tourism involved travel to unspoiled places to experience and enjoy nature (Honey, 1999). People would visit that place to appreciate the nature and the environment. The new trend in tourism indicated that people like to learn and to gain experience from their exploration in the area. According to Fennell (2008) and Nasir et al., (2020), ecotourism or nature tourism would include traveling to relatively undisturbed or uncontaminated natural areas with the specific object of studying, admiring and enjoying the scenery and its wild plants and animals, as well as any existing cultural areas. Ecotourism had been the fastest growing segments of the tourism industry, but it presented special management challenges to ensure that the quality of the environment is preserved and well-conserved (Weaver \& Lawton, 2007; Mohamad et al., 2019).

The concept of Ecotourism had been in existence long before the terminology began to be used within tourism studies, although it was not often called by that term. The first formal definition of ecotourism is credited to Ceballos-Lascurain (1996), who defined it as travelling to relatively undisturbed or uncontaminated natural areas with the specific objective of studying, admiring, and enjoying the scenery, its wild plants and animal, as well as any existing cultural manifestations found in these areas. In addition, Beaumont (1998) approached to ecotourism suggested that ecotourism as a subset of nature tourism, which in turn, is a subset of tourism. The three main principles, which were also common to other definitions of ecotourism, were the natural setting, ecological sustainability, and environmental education or interpretation (Page \& Dowling, 2002).

As elaborated by Fennel (1999), ecotourism is a form of sustainable form of natural resource-based tourism that focused primary on experiencing and learning about nature and which when ethnically managed should cause low impact on the environment. He added that it would typically occurred in natural areas and should contributed towards conservation or preservation such as areas. Attraction tourism inventories could be distinguished from natural, constructed or cultural forms (Fennell \& Dowling, 2003). Besides the riches of the nature, culture as indicated by Wearing and Neil (1999) the basic motives for traveling to nature or ecotourism sites would also be to observe cultural events or other cultural aspects of the community in the area.

\section{Research Methodology}

The study required the combination of exploratory and descriptive research designs. The exploratory design is used due to the unknown and unclear dimensions and the depth of 
the findings on the site. The descriptive design is used to examine the various conditions of resources.

On-site interviews with community members and leaders to derive their opinions and general interest and support for touristic activities in the area. Most of the data and information were collected via observational methods during the span of one week. The secondary data and information were gathered from published journal articles and books, and from research reports and from information supplied by the state tourism office and the public records from local district offices which is located at Kuala Pilah, the main administrative offices for this area. The secondary information form the basis for developing the open-ended for the interview sessions and also the instrument used in the primary data collection on the various resources analysis. A final analysis combined the responses from various sources and different perspectives from the local authorizes, the community members and leaders of Kampung Bukit Laka.

Primary data resources were collected guided by the instruments as shown in the following part:

Instrument 1: Site and location analysis checklist comprised of the following features:

- Area economics

- Physical characteristics

- Size and shape

- Land costs

- Utilities availability

- Street patterns

- Traffic information

- Visibility of the area

- Local labour

- Other services

Instrument 2: Natural resources analysis checklist comprised of the following elements:

- Beaches

- Coral reefs

- Mountains

- Forest reserves

- Waterfall 
- Lakes

- Rivers

- Caves

- Wildlife

- Springs

Instrument 3: Cultural resources analysis checklist comprised of the following elements:

- Historical buildings

- Historical sites

- Monuments

- Archaeological site and collection

- Folklore and tradition

- Handicrafts

- Museum

- Visual performing and fine art

- Research centre

Instrument 4: Community resources analysis checklist comprised of the following features:

- Community site.

- Population density.

- Perception on community development.

- Major types of residence.

- Condition of residence.

- Community surrounding.

- Community ethnic background.

- Household and family size.

- Average age head of household.

- Major source of household income.

- Economic activities around residence.

- Social status of community.

- Recreational activities around residence.

- Major household transportation mode. 


\section{Study Findings}

\section{Historical Perspective of Kampung Bukit Laka}

Researcher had interviewed Dato Lela Raja Hj Alias Bin Abd Karim, the community leader of Kampung Bukit Laka. According to him, the name Kampung Bukit Laka is derived from the history of the Minangkabau people who came from Sumatra in 1917 via the Muar River. The Minangkabau people were made up of twelve clans and they mixed and married the local people at Kampung Bukit Laka. The Kampung Bukit Laka, district of Jempol, in the early years, comprised of several villages such as the Kampung Kuala, Kampung Penarikan, Kampung Jempol, Kampung Batu Gatak, Kampung Kuala Sialang, Kampung Lonek, Kampung Batu Kikir,and Kampung Bukit Perah. In 1945, just after the end of the Japanese occupation of the country, a clash broke out in Kampung Batu Kikir between the village community and the communist terrorists. The clash started when a group of villages in Kampung Batu Kikir went out to rescue a religious teacher who was caught by a communist terrorist and he was detained at the communist headquarters in Kuala Pilah. The story was narrated the story community leader of Kampung Bukit Laka. The Malay community used traditional weapons made from carved rocks called 'batu kikir' while the communist forces used rifles. However, the community won the ensuing clash. This clash had gone down in history that reflected the spirit of struggle of the community of Batu Kikir.

Presently, 30\% of the land area Kampung Bukit Laka remained undeveloped, another $30 \%$ is covered with oil palm plantation area, $10 \%$ is developed with under construction with the housing project, and the balance $30 \%$ are the houses of the community which is spread over a wide area throughout Kampung Bukit Laka.

\section{Site and Location Resources Analysis}

An analysis of the site showed that $80 \%$ of the community own cars. There were two bus stop along the main road, but the buses were seldom seen plying the area. Quite a number of the community members had some small-scale businesses especially food stalls which served both the local community and the traffic passing through the village. Public buses and taxis were available. There was a main road with several junctions to smaller road leading to residential areas. The air in Kampung Batu Kikir was clean devoid of any air, water, or noise pollutions. The village is fully equipped with electricity and water supply and also telephone lines. Other facilities and services available were the police station, fire brigade, health clinic, post office, shop lots, a petrol station, and primary and secondary schools. Next to Kampung Bukit Laka is Kampung Lonek where there was a homestay. 
Other accommodation types, the hotels and guests' houses were available in the town of Kuala Pilah and Bahau.

Table 1 Site and Location Resources

- Homestay (Kampung Lonek) 2 km from Kampung Bukit Laka.

- Hotel and small hotel at Kuala Pilah and Bahau town nearby that area.

- Public utilities (electricity supply, water supply and telephones lines)

- Public amenities around villages (shop lot, school, restaurant, police station, post office, bus stand, community hall, mosque, petrol station and many more facilities around the villages and the town).

\section{Community Resources Analysis}

The main language spoken in Kampung Bukit Laka was the Malay language. The average family size was about 3 to 4 members. A majority of the youth and young adults live and work outside the village area. A majority of them worked in the private or public sectors (50\%) Those villagers who stayed and worked in Kampung Bukit Laka were selfemployed and involved in small scale agricultural activities (20\%), another $2 \%$ worked as farmers and $10 \%$ had food stall businesses. The tradition dessert the place is known for was the "Cendol Juasseh" a stall located just 3 kilometers outside the village. The villages were also known for its traditional food called as "Ubi Kayu" or tapioca which is popularly served during tea time and sometimes it would be served as dessert with topping coconut cream and brown sugar.

The population of Kampung Bukit Laka comprised mainly of adult people (about 40\%) with over 40 years old, while the young adults whose aged ranged between 20 and 40 years old adult made up $20 \%$ of the population. Another $20 \%$ were those under 20 years old. The other $20 \%$ were school going children.

The community residents were mainly made up of wooden traditional houses $(60 \%)$ and $40 \%$ were modern concrete houses. These houses tended to cluster in small groups, but the compound of the houses traditional houses was well-kept and clean. The major types of community economic activities were planting agricultural products such as coconut, rubber industry, oil palm plantations and paddy fields. Some community members worked from home, especially the female group where they would weave rattan baskets, or they sell food at stalls close to their homes. Some domestic animals such as goats, cows and chickens were reared by the community around the compound of their houses. 
Table 2 Community Resources

- Population: About 200 people

- $100 \%$ were of the Malay ethnic group. Average family size was 3 to 4

- Private or government sectors (50\%) self-agricultural activities (20\%), farming activities (20\%), self-employed in business activities (10\%)

- Population density senior citizen (40\%), (20\%) young adults, and other were school going age.

- Traditional house $(60 \%)$ and (40\%) modern concrete house

- Food stall famous "Cendol Juasseh" 2 km from Kampung Bukit Laka

- Traditional food "Ubi Kayu" or tapioca. Usually for teatime or desert served with topping coconut paste (Santan) and brown sugar

In general, many activities, religious or otherwise, were plan, organize and implemented as a community group. Community activities would be carried out in the community hall or the mosque. However, the community would usually keep a close tie with those of the same clan and each clan would be headed by Dato Lembaga. The following table showed the different names of clan and the title of the clan's head.

Table 3 Community Group Clusters

\begin{tabular}{|l|l|}
\hline Name of Clan & Title of Head (Lembaga) \\
\hline Tiga Batu Lela Raja & Dato Lela Raja \\
\hline Tanah Data & Dato Seri Amar Menteri \\
\hline Tiga Batu Maharaja Setia & Dato Maharaja Setia \\
\hline Tiga Batu Setia Raja & Dato Setia Raja \\
\hline Mungkal & Dato Komo \\
\hline Biduanda Waris & Dato Ombi/Dio Maharaja/Bentara \\
\hline Seri Melenggang & Dato Raja Senara/Dato Jengkaya \\
\hline Anak Acheh & Dato Seri Pahlawan \\
\hline Seri Lemak Pahang & Dato Setia Pahlawan \\
\hline Tiga Nenek & Dato Setia Penghulu \\
\hline Batu Hampar & Dato Besar \\
\hline Paya Kumbuh & Dato Sura \\
\hline
\end{tabular}

\section{Natural Resources Analysis}

The total size of Kampung Bukit Laka area is about 1 square acres. The landscape Kampung Bukit Laka is mainly flat land suitable for used as agricultural activities. Located nearby are the villages of Kampung Lonek, Kampung Kuala Sialang and Kampung Jempol which had more natural resources. Those villages were in the same sub-district as Kampung Bukit Laka. Thus, there were potential of several tourism products. Nearby, were the Gunung Angsi, Bukit Baginda, Bukit Putus, Wave Rock, Taman Eko Rimba and the Jeram Tengkek Waterfalls which the state had designated as 
ecotourism recreation sites. There were recreational activities such as mountain hiking, jungle tracking or the river recreation areas for picnic and camping.

\section{Table 4 Natural Resources}

- Area Sizes: 1 acres

- Status Land: $100 \%$ by own community villagers

- Land Status: Flat land suitable for ecotourism and agriculture activity.

- Kuala Pilah area: (Gunung Angsi, Bukit Baginda, Bukit Putus, Wave Rock and Taman Eko Rimba).

- Hutan Lipur Serting $8 \mathrm{~km}$

- Air Terjun Jeram Tengkek, Batu Kikir, nearby to Kampung Bukit Laka

\section{Cultural Resources Analysis}

There were some cultural resources elements found in Kampung Bukit Laka, and they included historical sites, monuments, archaeological sites and collections, and folklore and traditions. About 5 kilometres away from Kampung Bukit Laka, is located a museum of Pendeta Zaaba which was dedicated to the life of the renowned Malay writer Zainal Abidin bin Ahmad (Buyong Adil, 1981).

\section{Identification of Potential Tourism Products and Target Tourists Segments}

The tourism products in and around Kampung Bukit Laka focused mainly on culture and heritage, especially in Batu Kikir in the district of Jempol. Tourists could learn about the unique culture of the people of Negeri Sembilan. Other than that, the coconuts, oil palm and rubber plantations and the paddy fields could provide tourists with hands on experience on the handling of those plants. Tourists could also participated in handicraft making activities such as rattan basket weaving.

As an educational tourism product, the Pendeta Zaaba museum could contribute to attract tourists to better understand the literary work of the renowned Malay Language writer. He had been credited with modernizing the Malay language and pioneering grammatical rules through the publication of a series of grammar books.

The nature and Ecotourism products were in abundance around Kampung Bukit Laka. They would be attractive for tourists who would be interested in adventure and outdoor activities. About 30\% of the land area in Kampung Bukit Laka that were covered with thick, secondary jungle area could be tapped and converted into recreation activities for those tourists who seek outdoor challenges; and also for those plants enthusiast who wish to learn the medicinal aspects of jungle plants would be interested to venture into those 
jungles accompanied by the local guide. Thus, the following summarizes the potential tourism products of Kampung Bukit Laka and the identification of potential tourists segments:

1. Agro-based tourism products which could provide knowledge and learn about oil palm, rubber, and coconut plants and to conduct scientific research on horticulture aspects such as the medicinal plants of the jungle.

Tourist segments: Foreign and local tourists - small group or individual students and the scientific and research enthusiasts.

2. Nature and ecotourism-based products: Provided challenging, outdoor recreational activities.

Tourists segments: Foreign and local adult individual tourists seeking outdoor adventure.

3. Culture and heritage products: Learning about the clan structure and their rituals and traditions.

Tourists segments: Foreign and local tourists interested on the study of the Minangkabau clans and their traditions.

4. Historical products: Appreciating Pendeta Zaaba contribution to the literary world. Historical events on the clash with the communists, and the Batu Kikir weapon.

Tourists segments: Foreign and local tourists interested on the Malay language and the historical aspects of Kampung Bukit Laka.

Kampung Bukit Laka could be designated as the tourism hub with the enormous and variety of tourists attractions within a 10 mile radius around the kampong.

\section{Summary and Conclusions}

Kampung Bukit Laka could be developed as a tourist destination hub as the village and its surrounding areas offered a variety of tourism products such agro-based, nature and eco-based, cultural and historical based tourism products, thus it had the ability to attract both local and international tourists who would be interested in those tourism products.

There are, however, challenges and issues to be looked into such as the development of proper planning which should include the local community and their leaders. The 
challenges would be (1) to get the cooperation of the different clans, (2) to coordinate the implementation of the plan, (3) to ensure that the environment would be conserved and remained unspoilt and (4) to ensure that the community would get a fair share of the development. The developmental plan would have to include the accessibility to all the attraction sites, proper signage, public facilities such as restrooms, and information centre, and also promotional activities to reach out to the target tourist segments.

\section{References}

Beaumont, N. (1998). The meaning of ecotourism according to... is there now consensus for defining this 'natural' phenomenon? An Australian perspective. Pacific Tourism Review, 2(3/4), 239-250.

Bernama (2017). The face of the traditional village is getting different. https://mediapermata.com.bn/wajah-kampung-tradisi-semakin-berbeza/

Buyong Adil (1981). Sejarah Negeri Sembilan. Kuala Lumpur: Dewan Bahasa dan Pustaka.

Ceballos-Lascurain, H. (1996). Tourism, ecotourism and protected areas: The state of nature-based tourism around the world and guidelines for its development. Cambridge: IUCN Publications.

Fallahi, A. (2008). An interdisciplinary analytical study on the risk preparedness of Bam and its cultural landscape, a world heritage property in danger in Iran. The Australian Journal of Emergency Management, 23(2), 20-29.

Fennell, D.A. (1999). Ecotourism: An introduction. London: Routledge.

Fennell, D.A. (2008). Ecotourism: An introduction. 3rd Editions. London: Routledge.

Fennell, D.A., \& Dowling, R.K. (2003). Ecotourism policy and planning. Oxon: CABI Publishing.

Hofstede G (1991). Culture and organizations. Maidenhead: McGrawHill.

Honey, M. (1999). Ecotourism and sustainable development: Who owns paradise? Washington: Island Press.

Mohamad, M., Nasir, M.N.M., Ab Ghani, N.I., \& Afthanorhan, A. (2019). Parallel mediators of place attachment and tourist satisfaction in destination attractiveness, destination loyalty and service quality. International Journal of Innovation, Creativity and Change, 7(7), 228-256.

Nasir, M.N.M., Mohamad, M., Ghani, N.I.A., \& Afthanorhan, A. (2020). Testing mediation roles of place attachment and tourist satisfaction on destination attractiveness and destination loyalty relationship using phantom approach. Management Science Letters, 10(2), 443-454. https://doi.org/10.5267/j.msl.2019.8.026

Page, S.J., \& Dowling, R.K. (2002). Ecotourism: Themes in tourism. Harlow: Prentice Hall.

Reed, M.G. (1997). Power relations and community-based tourism planning. Annals of Tourism Research, 24(3), 566-591.

Trompenaars, F. (1993). Riding the waves of culture: Understanding cultural diversity in business. London: Breatley; Briscoe, DR, \& Shuler, RS 2004. International human resource management, 2. 
Webology, Volume 18, Special Issue on Current Trends in Management and Information Technology, October, 2021

Wearing, S., \& Neil, J. (1999). Ecotourism: Impacts, potentials and possibilities. Melbourne: Butterworth-Heinemann.

Weaver, D.B., \& Lawton, L.J. (2007). Twenty years on: The state of contemporary ecotourism research. Tourism Management, 28(5), 1168-1179.

Sigo, M.O., Selvam, M., Venkateswar, S., \& Kathiravan, C. (2019). Application of ensemble machine learning in the predictive data analytics of indian stock market. Webology, $16(2), 128-150$. 